УДК 159.9.07:316.613]:364.624.4 DOI https://doi.org/10.32843/26635208.2020.13-1.24

\section{Кравченко О.О.}

д.пед.н.,

професор кафедри соціальної

педагогіки та соціальної роботи Уманський державний педагогічний університет імені Павла Тичини Міщенко М.С.

к.психол.н., доцент кафедри психології Уманський державний педагогічний університет імені Павла Тичини

\begin{abstract}
Безпосередньо пандемія призвела до закриття підприємств у країнах з високим відсотком хворих, різкого зростання попиту на продукти повсякденного використання, спекуляцій на ринку певних товарів: противірусних препаратів, санітарних масок, дезінфрікувальних засобів.

Карантин тягне за собою негативні наслідки для економіки, прямо або побічно спричиняє зупинку цілих галузей або зниження їхньої продуктивності. Економічне руйнування призводить до того, що десятки мільйонів людей втрачають свої робочі місия, оскільки торгівля й виробництво просто зупиняться.
\end{abstract}

Торгівля, логістика й транспорт - найбільш потужні драйвери сучасного економічного зростання. Бізнес стикається з дефрiцитним фрінансовим потоком із незнайомою досі кризою пропозиції. Населення в результаті вимушеного простою виробництва втрачає доходи й поточну платоспроможність. Українська та світова медичні системи не готові до лікування коронавірусу. Для наукового й медичного світу нинішній досвід протистояння спалаху Covid-19 виявиться надзвичайно чінним.

Ізоляція ділить людей на два типи: одні насолоджуються домашнім затишком і вільним часом, а інші не знаходять собі місця й хочуть якомога швидше повернути свободу. Але в підсумку карантин негативно позначиться на психічному й фізичному здоров'ї і тих і тих, тому що ми соціальні істоти, довге усамітнення чинить руйнівний вплив на нас.

Подія такого масштабу не може не вплинути на наш психологічний стан: вимушена ізоляція, неможливість робити багато звичних речей і бачитися наживо з друзями й рідними, новини про зростання числа заражених і загиблих, страх за себе та близьких людей викликають тривогу й напруження навіть у тих, хто в інший час такого не відчуває.
Ключові слова: карантин, ізоляція, психологічний стан, психологічні проблеми, категорії населення, пандемія.

Directly, the pandemic has led to the closure of enterprises in countries with a high percentage of patients, a sharp increase in demand for everyday products, speculation in the market of certain goods: antiviral drugs, sanitary masks, disinfectants.

Quarantine has negative consequences for the economy, directly or indirectly affecting the shutdown of entire sectors of the economy or reduce their productivity. Economic ruin will result in tens of millions of people losing their jobs as trade and production simply cease.

Trade, logistics and transport are the most powerful drivers of modern economic growth. Business is facing a scarce financial flow and a hitherto unknown supply crisis. The population loses income as a result of forced downtime and current solvency. Ukrainian and world medical systems are not ready for coronavirus treatment For the scientific and medical world, the current experience of countering the Covid-19 outbreak will be extremely valuable.

Isolation divides people into two types: some enjoy home comfort and free time, while others do not find a place and want to regain their freedom as soon as possible. But in the end, quarantine will negatively affect the psychological and physical health of both the first and the second, because we are social beings and long solitude has a devastating effect on us.

An event of this magnitude can't but affect our psychological state: forced isolation, inability to do many familiar things and see live with friends and family, news of the growing number of infected and dead, fear for themselves and loved ones cause anxiety and tension even in those who does not feel it at other times. Key words: quarantine, isolation, psychological state, psychological problems, population categories, pandemic.
Постановка проблеми. Мільйони людей по всьому світі змінили звичний спосіб життя, щоб запобігти поширенню пандемії коронавірусу. Пандемія коронавірусу Covid-19 загрожує не тільки здоров'ю українців, а й економіці країни. Безпосередньо пандемія призвела до закриття підприємств у країнах з високим відсотком хворих, різкого зростання попиту на продукти повсякденного попиту, спекуляцій на ринку певних товарів: противірусних препаратів, санітарних масок, дезінфікувальних засобів. Карантин тягне за собою негативні наслідки для економіки, прямо або побічно спричиняє зупинку цілих галузей економіки або зниження їхньої продуктивності. Економічне руйнування призводить до того, що десятки мільйонів людей втратять свої робочі місця, оскільки торгівля й виробництво просто припиняться.

Карантин як крайній захід ізоляції дійсно може спричинити порушення в людській психіці, в тому числі й в абсолютно нормальних людей. Довгострокові дослідження показують, що й через довгий час після зняття карантину ймовірність порушень, пов'язаних зі страхами, розладом сну або посттравматичними навантаженнями, залишається підвищеною.

Аналіз останніх досліджень і публікацій. Проблемою дослідження впливу супутніх негативних явищ на психіку людини в умовах різних видів ізоляції займалися, зокрема, Є.М. Потапчук (збереження психічного здоров'я) [6]; А.Б. Коваленко, М.Н. Корнєв [4]; О.Н. Кузнєцов, В.І. Лєбєдєв, М.М. Ханаіашвілі, П.Б. Ган- 
нушкін, Е.І. Кречмер (вплив умов соціальної ізоляції на особистість і міжособистісні відносини) [1; 5, с. 34], І.К. Кеєлєйников, І.Ф. Рябінін (особливості спілкування в умовах групової ізоляції) [2, с. $34 ; 3$, с. 83].

Постановка завдання. У своєму дослідженні ми намагалися дослідити психологічний стан в умовах ізоляції, а саме карантину.

Виклад основного матеріалу дослідження. Новизна і невизначеність умов життя суспільства в режимі карантину вимагають усвідомлення i спеціальних заходів щодо пом'якшення пережитого соціального шоку, особливо щодо надання інформації й тривалості карантину.

Детальніше розглянемо психологічні проблеми, які активізуються під час карантину.

1. Тривожність. У зв'язку з появою інформації про нове захворювання та його масштабне розповсюдження по світу в суспільстві різко збільшується рівень тривожності. Величезна кількість інформації, часто суб'єктивної, непоясненої й неперевіреної, надходить з усіх можливих джерел. У людей, схильних до тривожних реакцій, у надзвичайних ситуаціях можуть загострюватися прояви тривоги, в тому числі панічні атаки. I справа тут не в ізоляції, а в неспокійній ситуації загалом. Тривога змушує нас приділяти більше уваги заходам захисту. У людей підвищується базовий рівень тривожності й загострюється недовіра одне до одного, до тих, хто чхає, кашляє тощо. У людини завжди є внутрішнє напруження, коли вона йде на захід з великим скупченням людей, і зараз цей рівень напруги загострюється.

2. Почуття невизначеності базується на традиційній недовірі українців до будь-якої влади. Ситуація невизначеності викликає в людей спочатку розгубленість, загострене відчуття, що втрачаєш контроль над усіма сферами свого життя. А вже потім наростає паніка. Ще один момент - боязнь майбутнього та змін, ми не знаємо, скільки триватиме карантин. Цей природний стан $є$ в усіх. Але важливо, щоб цей страх переростав у якісь життєві дії, досягнення, мету й результат. Зараз тривога й страх, загострюючись, відвертатимуть увагу людей від процесів самореалізації та створюватимуть захисну метушню.

3. Паніка. Паніка позбавляє можливості тверезо аналізувати й реагувати адекватно. Паніка і дистрес (негативний тип стресу) знищують людей так само, як вірус. Дистрес характеризується зниженням працездатності, пригніченим станом, різкими перепадами настрою, безсонням, дратівливістю і зниженням імунітету. Людьми, які перебувають у цьому стані, дуже просто керувати. Паніка знижує або повністю виключає критичне мислення, і людина легко піддається навіюванням і самим абсурдним твердженням. Паніку погіршили новини фінансово-економічні.
4. Депресія. Сприяє підвищенню напруженості те, що доводиться адаптуватися до нових умов, нерідко відчувати фінансові проблеми. Саме брак спілкування - основна причина депресії, яка розвивається через самоізоляцію. Також на психічне здоров'я впливає те, що в нас зникають звички з нормального життя. Все це породжує нудьгу й незадоволеність, а також почуття ізоляції від усього світу.

5. Почуття самотності. Люди, які живуть самітно, можуть відчути себе більш самотніми - навіть якщо за звичайних обставин їм цілком комфортно без відносин. Вимушена ізоляція досить важке переживання, навіть для тих, хто вважає себе інтровертом і не відчуває потреби в щоденному тісному спілкуванні.

6. Конфлікти. 3 огляду на умови карантину, багатьом доводиться перебувати в одному приміщенні з одними й тими ж людьми, в одних і тих самих стінах, маючи мало різноманітності у своєму дозвіллі. У зв'язку з цим є висока ймовірність виникнення конфліктів, непорозуміння й роздратування, проблем у стосунках.

7. Страх. Страх перед невизначеністю провокує високий рівень тривоги й масові закупівлі в магазинах. Страх перед невідомим захворюванням стає джерелом багатьох переживань і хаосу.

Також для багатьох людей характерний страх смерті. Це комплекс тривожних переживань щодо власної смерті або смерті близьких людей. Люди бояться померти, тому що цей страх необхідний для виживання.

8. Стрес. Люди мають різні психологічні параметри, що допомагає їм з різною модальністю реагувати на зниження інтенсивності соціального життя. Хтось страждає через неможливість здійснювати тривалі прогулянки, інші - від дефіциту тактильних відчуттів, від розлуки з коханими, від необхідності пережити карантин із дітьми в дуже обмеженому просторі. Головне - усвідомити, що кожен із нас сьогодні веде боротьбу зі своїм власним стресом. Навіть якщо причини стресу в іншої людини не мають нічого спільного з нашими, страждаємо ми, швидше за все, однаково інтенсивно. Будь-який стрес має три стадії: активація, протистояння, виснаження. Перебуваючи довго у стані стресу, нервова система людини виснажується, імунітет слабшає. Тому будь-які панічні стани впливають негативно, організм не повністю використовує свої сили, тому що виснажуються ресурси.

Різні категорії населення по-різному реагують на ситуацію, яка склалася в Україні.

Діти. Описуючи реакцію на ситуацію, у якій перебуває сьогодні наша країна, 3 позиції дітей, виникає потреба розмежувати період дитинства на дошкільний і молодший шкільний вік, оскільки є відмінності у сприйманні й розумінні дітьми явища «карантин». Соціальна ситуація розвитку в дошкільному віці характе- 
ризується тим, що в дитини з'являється коло елементарних обов'язків; змінюються взаємини з дорослими, набуваючи нових форм: спільні дії поступово змінюються самостійним виконанням дитиною вказівок дорослого; 3'являється можливість системного навчання; дитина вступає у певні стосунки з однолітками (розширюється оточення); внутрішня позиція дошкільника стосовно інших людей характеризується усвідомленням свого «я» та своїх вчинків, величезним інтересом до світу дорослих, їхньої діяльності та взаємин; дитина діє, як доросла людина, але у формі сюжетно-рольової гри. Соціальна ситуація розвитку дитини дошкільного віку має таку схему: дитина сюжетно-рольова гра - соціальне оточення.

Створення сприятливих умов для дітей дошкільного віку - $€$ важливим завданням у період ізоляції, оскільки цей період $є$ важливим у формуванні дітьми соціальних зв'язків і $є$ нагальна потреба окреслити для дітей ситуацію (у форматі сюжетно-рольової гри), у якій перебуває суспільство, чому не можна проводитичасзісвоїмидрузями, запрошуватиїхвгості та разом гратися на дитячому майданчику.

Психічний і особистісний розвиток дитини в молодшому шкільному віці зумовлюється особливістю соціальної ситуації розвитку навчання в початковій школі. На цьому віковому етапі провідною діяльністю стає навчання, основою якого є пізнавальний інтерес і нова соціальна позиція.

Молодь. Теперішній період розвитку нашої країни характеризується нестабільністю всіх сфер життя суспільства. Відповідно нестабільне й життя окремої людини. Успішність чи неуспішність життєвого шляху особистості залежить від її власних зусиль, від здатності швидко адаптуватися до мінливих обставин, особливо саме зараз, у період карантину. Це становище накладає відбиток на процес формування молоді як певного соціального зрізу суспільства, обумовлює велику варіативність в особистому ставленні молодих людей до сьогодення, призводить до перегляду молоддю життєвих цінностей, власних принципів.

Хочеться вірити, що значна частина молоді сприймає карантин як час зайнятися тим, про що давно мріяв або відклав на потім. Добре, коли молодь у період ізоляції займається самовдосконаленням, самоосвітою та фізичною активністю. І цьому є підтвердження - соціальні мережі. Молоді люди організовують у них марафони, челенджі - спортивні, з опанування нових знань, просто ставлять собі завдання перед аудиторією задля того, аби не закинути справу, а довести її до кінця, оскільки пообіцяв не лише собі, а і своїм друзям. Це хороший спосіб, який мотивує ставати кращим навіть із певними обмеженнями, так би мовити, бо спортзали закриті, курси не проводяться очно, спілкування живого активного немає. Це час, який дає ґрунт подружитися з самим собою, пізнати самого себе, полюбити себе, навчитися прислухатися до внутрішнього голосу.

Працездатні. Кожна з ієрархії потреб, яку описав Маслоу, на наш погляд, зараз «пригальмовує» свою можливість на задоволення. Тому важливо з холодним розумом підходити до будь-якого питання, особливо якщо це стосується особистості, оскільки наслідки можуть бути непередбачувані. Озлобленість, алкоголізм, наркоманія, безробіття, втрата бізнесу, втрата близької людини, крадіжки, вбивства, депресивні стани - це невеликий перелік того, що можна очікувати і з чим доведеться працювати наступні найближчі роки.

Люди похилого віку. Похилий вік так само, як і будь-який інший віковий етап онтогенезу людини, має нерівномірність змін і гетерохронність фаз розвитку. Одна з головних психологічних особливостей людей у літньому віці - почуття самотності. На жаль, для цього часто є об'єктивні підстави: брак спілкування. Неувага з боку близьких, неможливість вести звичний спосіб життя. У пізній період життя людини спостерігається специфічне співвідношення між збереженням психофізіологічних функцій, дій, мотивації й особливостями особистості. Зниження психічного тонусу, сили й рухливості складає основну вікову характеристику психічного реагування в старості.

Характерні психологічні й фізіологічні зміни тісно взаємопов'язані в похилому віці. Деякі психологічні характеристики людей похилого віку (наприклад, негативне сприйняття дійсності), можуть бути наслідком фізіологічних змін в організмі. Ізоляція через коронавірус спіткала різних людей, але $є$ ті, хто в такій ситуації найбільшвразливий, - літні люди, особливо тіз них, кому потрібна допомога в побутових справах, з продуктами й медикаментами. Дослідження показують, що почуття самотності може посилювати в літніх людей уже наявні проблеми зі здоров'ям. Існує зв'язок між ізольованістю від суспільства й погіршенням здоров'я, наприклад розвитком деменції, серцево-судинних захворювань, інсульту й інших станів.

Почуття самотності виникає через різницю поколінь, літнім людям важко знайти порозуміння з дітьми й онуками, важко орієнтуватися в їхніх інтересах. Але в такій критичній ситуації ми маємо поступитися на благо кожного: потурбуватися про те, щоб було достатньо продуктів, медикаментів у своїх рідних, погодьтеся, не важко. А ще якщо кожного дня знайти кілька хвилин на дзвінок і впевнитися, що все гаразд, не складе труднощів ні для кого.

Люди 3 інвалідністю. Звісно, що людям з інвалідністю вдвічі важче будь-що пережити, зрозуміти й пристосуватися. Звичайно, ці 
стани не пов'язані з новим коронавірусом, але масштабні обмеження можуть перешкодити їм отримувати допомогу.

Пандемія коронавірусу й карантин змінили наше життя раптово, кардинально і, що найгірше, на невизначений термін. Ми замкнені по домівках і сильно обмежені в пересуванні. Потрібно постаратися звести до мінімуму потенційну шкоду соціальної ізоляції для психічного й фізичного здоров'я. Зробити так, щоб цей період був менш стресовим і більш ресурсним завдяки простим діям.

3 метою визначення психологічного стану в умовах ізоляції нами було проведено опитування. Воно проходило у два етапи: 1-й етап - початок оголошення карантину, 2-й етап - через місяць. У дослідженні взяли участь 53 особи: до 35 років чоловіки - 9,6\%, жінки - 32,7\%, 3 інвалідністю - 23,1\%; до 55 років чоловіки - 11,5\%, жінки - 25\%, з інвалідністю - 11,5\%; від 55 років чоловіки - 3,8\%, жінки - 17,3\%, з інвалідністю - 9,6\%.

Якщо порівнювати зміни до карантину й після нього, то показовим $€$ відсоток опитаних, які не відносять свій матеріальний стан до «значного»: якщо до карантину заможних українців було 5,8\% віком до 35 років та 1,9\% віком до 55 років, то після карантину їхня кількість зменшилася до єдиного показника 3,8\% (особи віком до 35 років). Середній рівень матеріального достатку також похитнувся в бік низького: якщо до карантину в опитаних був середній рівень 25\% (до 35 років), 28,8\% (до 55 років) та 11,5\% (від 55 років), то після карантину ситуація мала вже такий вигляд: 26,9\% (до 35 років), 23,1\% (до 55 років), 9,6\% (від 55 років). Спостерігається ситуація коли українці зі значним матеріальним станом переходять до середнього рівня, а представники середнього рівня - до низького. Загалом, якщо враховувати, що на початку карантину опитаних із низьким рівнем було 9,6\% (до 35 років), 5,8\% (до 55 років), 7,6\% (від 55 років), то по закінченню результати були такими: 9,6\% (до 35 років), 13,5\% (до 55 років), 9,6\% (від 55 років). Це свідчить про те, що період карантину різко змінив матеріальний стан українців. Саме цей факт найбільше вплинув на психічний стан населення. Порівнюючи результати в таблиці, можна зробити висновок, що молодь (до 35 років) краще змогла адаптуватися до складних економічних умов, більшість на момент закінчення карантину залишилася в такому ж соціальному стані, як і до нього. Можливо, це пов'язано з більшою соціальною активністю, меншою сприйнятливістю тривожного соціального настрою, здатністю опанувати таку нову форму роботи, як дистанційна.

Більшість українців $(32,7 \%$ до 35 років, $34,6 \%$ до 55 років і 19,2\% від 55 років) на момент початку карантину були впевнені в тому, що є пряма залежність між матеріальним і психологічним станом особистості. По закінченню карантину кількість опитаних із такою ж думкою збільшилось: $34,6 \%$ до 35 років, 36,5\% до 55 років і 19,2\% від 55 років, що свідчить про те, що за умов нестабільного матеріального стану в населення збільшується кількість психологічних проблем.

Люди з більш високим рівнем достатку відчувають більш високий рівень психологічного благополуччя, оскільки в них $€$ певні заощадження. Це проявляється в упевненості в завтрашньому дні й загальному емоційному стані, але не зменшує почуття тривоги та страху за смерть близьких.

Люди з низьким рівнем достатку перебувають у стресі, для них характерні ознаки депресії, тривожності, паніки, втоми, розладів сну, тому що в більшості основний дохід - заробітна плата, яку зараз не отримують. У людей виникає страх витрачати всі гроші на свої базові потреби, оскільки перебувають в ситуації невизначеності за свою роботу.

Якщо досліджувати питання найбільш поширених труднощів, які спіткали опитуваних до й після карантину, то як у першому, так і в другому випадку більшою є кількість українців, які обрали варіант «психологічні проблеми». Тому сьогодні надзвичайно затребуваною є психологічна допомога фахівців, які б стабілізували тривожно-фобічні стани населення.

На питання, хто допоміг впоратися із проблемами, на початку карантину більшість опитаних визнали, що самостійно долають труднощі: 23,1\% до 35 років, 25\% до 55 років. На період закінчення карантину виявилося, що саме близькі й рідні завжди поруч і в усьому допомагають: 23,1\% до 35 років, 23,1\% до 55 років. Особи після 55 років в обох випадках опікуються рідними, про що свідчать результати (15,4\% від 55 років). Можна спостерігати, що важка ситуація змусила велику частину українців зняти з себе зайву відповідальність і розділити її з близькими, дозволити їм взяти частину обов'язків, проблем на себе.

Будь-яка проблема змінює щось у нашому світогляді, це доводять і результати опитування: на час закінчення карантину більшість українців упевнені, що такі умови життя дуже вплинули на світобачення й ставлення до речей (25\% до 35 років, 25\% до 55 років та 13\% від 55 років).

Найбільшою проблемою для населення обернулася неможливість працювати у звичному режимі, лише дистанційно $(21,2 \%$ до 35 років) або рішення роботодавця про неоплачувану відпустку $(21,2 \%$ до 35 років, $17,3 \%$ до 55 років і 15,4\% від 55 років). Оплачувана відпустка була надана лише 7,6 \% віком до 35 років і 7,6\% віком до 55 років. Як бачимо, дистанційно під час карантину працювала 
лише молодь, дехто зміг отримати можливість піти у відпустку з оплатою, проте помітній більшості довелося піти у відпустку за власний рахунок. Проблема полягає в тому, що дистанційно організувати роботу не всюди можливо, лише в більшості державних установ. Приватним підприємствам більш раціонально відправити працівників або в неоплачувану відпустку або ж звільнити (опитування звільнених не виявило).

Якщо характеризувати психічне благополуччя, то на момент початку карантину більшість опитаних страждали від депресивного стану $(19,2 \%$ до 35 років, 17,3\% до 55 років та 9,6\% від 55 років). На період закінчення карантину в депресивному стані перебувають 23,1\% до 35 років, 9,6\% до 55 років і 7,7\% від 55 років, крім цього значна кількість українців втратили впевненість у завтрашньому дні (17,3\% до 35 років, 15,4\% до 55 років і 15,4\% від 55 років). Причинами такого рівня психічного благополуччя можна вважати різку зміну соціального стану, відособлення від суспільства, невідомість майбутнього, неможливість забезпечити надійну безпеку собі та близьким.

Здорового способу життя на початку карантину дотримувалася більшість (32,7\% до 35 років, 23,1\% до 55 років й 11,5\% від 55 років). По закінченню карантину показник не надто змінився: (34,6\% до 35 років, 26,9\% до 55 років й 11,5\% від 55 років). Можна зробити висновок, що карантин майже не вплинув на дотримання опитуваними здорового способу життя: українці намагаються це робити, незважаючи ні на що.

Дослідження показали, що найбільшим мотиватором до карантину для молоді (13,5\% до 35 років) і для осіб від 55 років $(21,2 \%)$ були близькі люди, для осіб до 55 років (13,5\%) фінансові можливості. Після карантину ситуація майже не змінилася, що свідчить про те, що населення ще не встигло адаптуватися до нормальних умов, а також про значну роль невідомості майбутнього.

За період карантину більшість українців дотримувалися розпорядку й режиму дня: 23,1\% до 35 років, 26,9\% до 55 років і 13,5\% від 55 років. Майже такою залишилася ситуація й після карантину.

За пріоритетністю цінностей у більшої частини молоді й осіб до 55 років перелік цінностей починається 3 двох найважливіших: сім'я (1), здоров'я (2). У віці від 55 років дещо змінюється тенденція: здоров'я (1), сім'я (2), що може свідчити про усвідомлення того, що без мінімального здоров'я все інше не так уже важливо. Окрім цього може спостерігатися типова поведінка людей після 55 років, коли вони, будучи не зовсім здоровими, почуваються тягарем для інших.

Більшість опитаних до 35 років (30,8\%) ніколи не порушували карантин, особи до 55 років (15,4\%) і від 55 років $(9,6 \%)$ зізналися, що іноді йшли на порушення правил карантину. Були й такі, які зовсім не дотримувалися правил карантину (1,9\%) серед осіб віком від 55 років.

Цікавими $є$ результати щодо майбутніх планів після карантину. Нічого не зміниться в їхньому житті на думку $23,1 \%$ опитаних до 35 років, 26,9\% віком до 55 років і 19,2\% віком від 55 років. Зате кардинально змінити життя планують 9,6\% українців віком до 35 років, 1,9\% віком до 55 років й 1,9\% віком від 55 років. Отже, значна більшість українців бажають увійти у спокійне, розмірене життя, повернутися до звичних справ і зручного режиму життя.

Висновки 3 проведеного дослідження. Психологічні наслідки карантину можуть бути тривалими й спричиняти зміни психологічного стану особистостіподібнодо тих, які виникають у людей, що зіткнулися з війною. Опинившись у соціальній ізоляції, люди інакше сприймають своє існування, починають переживати страх можливої смерті. Небезпека починає ховатися в безпосередньому оточенні, в публічному просторі. Видозмінюються й розриваються соціальні зв'язки, в яких формувалася особистість, відбуваються зміни в поведінці. Те, що було ресурсом життя, сприймається як потенційна загроза, - ця ситуація стає екзистенційним викликом, який потрібно якось пережити особистості й суспільству. Все це призводить до нетипових переживань, стресів і психологічно травмує особистість, впливає на суспільні процеси.

В результаті опитування було з'ясовано, що саме соціальна ізоляція, яка позбавляє людину суспільних контактів, комунікації, можливості реалізації власних особистісних ресурсів, стає причиною руйнівних процесів в організмі людини, наслідком чого $є$ не лише погіршення фізичного самопочуття хворого, а й зміни його особистості, відхилення в емоційно-вольовій і мотиваційній сферах.

Таким чином, соціальна ізоляція в умовах карантину є першопричиною погіршення психологічного здоров'я людини, адже обмежує свободу дій й ініціативу, активність і самостійність, можливості усвідомлення своєї індивідуальності, мінімізує активність і творчість у самих різних сферах життя й діяльності, припускає втрату інтересу людини до життя, здатності до сильних почуттів і переживань. 


\section{ЛІТЕРАТУРА:}

1. Горбов Ф.Д. Психоневрологические проблемы труда операторов. Москва : Прогресс, 1975. 254 с.

2. Келейников И.К. Конформизм и распределение ролей в условиях длительной изоляции. Клинико-психологические исследования личности. Ленинград, 1971. С. 34.

3. Келейников И.К. Социометрическая процедура и индивидуальное тестирование малых групп, находящихся в экстремальных условиях. Труды Новосибирского государственного медицинского института. Новосибирск, 1971. Т. 57 : Вопросы клинической психологии и экспериментальной психиатрии. С. 83.

4. Коваленко А.Б., Корнєв М.Н. Соціальна психологія : підручник. Київ, 2006. 400 с.

5. Кузнецов О.Н., Лебедев В.И. Достоевский о тайнах психического здоровья. М., 1994. 387 с.

6. Потапчук Є.М. Соціально-психологічні основи збереження психічного здоров'я військовослужбовців : дис. ... доктора психол. наук : 19.00 .09 ; Національна академія Державної прикордонної служби України ім. Богдана Хмельницького. Хмельницький, 2004. 366 c. 